\title{
In vitro differential activity of phospholipases and acid proteinases of clinical isolates of Candida
}

\author{
Atividade diferencial in vitro de fosfolipases e proteinases ácidas de isolados clínicos de Candida
}

\author{
Aurean D’Eça Júnior ${ }^{1,2}$, Anderson França Silva ${ }^{3}$, Fernanda Costa Rosa ${ }^{1}$, Sílvio Gomes Monteiro ${ }^{1}$, \\ Patrícia de Maria Silva Figueiredo ${ }^{1}$ and Cristina de Andrade Monteiro ${ }^{1,3}$
}

\begin{abstract}
Introduction: Candida yeasts are commensals; however, if the balance of normal flora is disrupted or the immune defenses are compromised, Candida species can cause disease manifestations. Several attributes contribute to the virulence and pathogenicity of Candida, including the production of extracellular hydrolytic enzymes, particularly phospholipase and proteinase. This study aimed to investigate the in vitro activity of phospholipases and acid proteinases in clinical isolates of Candida spp. Methods: Eighty-two isolates from hospitalized patients collected from various sites of origin were analyzed. Phospholipase production was performed in egg yolk medium and the production of proteinase was verified in a medium containing bovine serum albumin. The study was performed in triplicate. Results: Fifty-six (68.3\%) of isolates tested were phospholipase positive and $16(44.4 \%)$ were positive for proteinase activity. C. tropicalis was the species with the highest number of positive isolates for phospholipase (91.7\%). Statistically significant differences were observed in relation to production of phospholipases among species $(p<0,0001)$ and among the strains from different sites of origin $(p=0.014)$. Regarding the production of acid protease, the isolates of $C$. parapsilosis tested presented a larger number of producers $(69.2 \%)$. Among the species analyzed, the percentage of protease producing isolates did not differ statistically $(\chi 2=1.9 \mathrm{p}=0.5901(\chi 2=1.9 \mathrm{p}=0.5901)$. Conclusions: The majority of C. non-albicans and all C. albicans isolates were great producers of hydrolytic enzymes and, consequently, might be able to cause infection under favorable conditions.
\end{abstract}

Keywords: Candida. Virulence factors. Phospholipases. Proteases.

\section{RESUMO}

Introdução: Candida são leveduras comensais, porém, se o equilíbrio da flora normal for interrompido ou as defesas imunitárias estiverem comprometidas, espécies de Candida podem causar manifestações de doença. Vários atributos contribuem na virulência e patogenicidade de Candida, inclusive a produção de enzimas extracelulares hidrolíticas, especialmente fosfolipases e proteinases. O objetivo deste estudo foi verificar a atividade in vitro de fosfolipases e proteinases ácidas em isolados clínicos de Candida spp. Métodos: Oitenta e dois isolados provenientes de pacientes hospitalizados coletados a partir de sítios de origem diversos foram analisados. A produção de fosfolipase foi verificada em meio egg yolk e a de proteinase em meio contendo soro albumina bovina. O estudo foi feito em triplicata. Resultados: Cinquenta e seis $(68,3 \%)$ dos isolados testados apresentaram atividade de fosfolipase positiva e $16(44,4 \%)$ foram positivos para atividade de proteinase. C. tropicalis foi a espécie que apresentou o maior número de isolados positivos para fosfolipases (91,7\%). Diferenças estatisticamente significantes em relação à produção de fosfolipases entre as espécies e entre as cepas provenientes de diferentes sítios de origem foram detectadas. Quanto à produção de proteinases ácidas, os isolados de C. parapsilosis testados foram os maiores produtores (69,2\%). Entre as espécies analisadas, a porcentagem de produção de proteinase entre os isolados não diferiu estatisticamente $(\chi 2=1.9 \mathrm{p}=0.5901(\chi 2=1.9 \mathrm{p}=0.5901)$. Conclusões: A maioria dos isolados de $C$. nãoalbicans, assim como os de C. albicans, foram grandes produtores de enzimas hidrolíticas e, consequentemente, podem ser capazes de causar infecção em condições adequadas.

Palavras-chaves: Candida. Fatores de virulência. Fosfolipases. Proteinases.

1. Pró-Reitoria de Pós-Graduação, Pesquisa e Extensão, Núcleo de Doenças Infecciosas e Parasitárias, Centro Universitário do Maranhão, São Luis, MA. 2. Departamento de Enfermagem, Instituto Florence de Ensino Superior, São Luis, Maranhão. 3. Departamento de Biologia, Instituto Federal de Educação, Ciência e Tecnologia do Maranhão, São Luís, MA.

Address to: Dra. Cristina de Andrade Monteiro. Pró-Reitoria de Pós-Graduação, Pesquisa e Extensão/ Uniceuma. Rua Josué Montello 1, Renascença II, 65040-000 São Luis, MA, Brasil.

Phone: 98 3214-4265

e-mail: crisand2003@yahoo.com.br

Received in 14/11/2010

Accepted in 10/01/2011

\section{INTRODUCTION}

The polyphyletic genus Candida includes species of pathogenic fungi in humans, including Candida albicans, C. glabrata, C. parapsilosis, C. tropicalis and other species. Together these species are responsible for $34 \%$ of opportunistic fungal infections and C. albicans is the most common fungal pathogen in humans. Over the past few years, the incidence of fungal infections by non-albicans species has increased ${ }^{1}$. The reasons for this change in the species distribution pattern in fungal infections have not been fully elucidated and may be closely related to the virulence potential of these microorganisms. Different species of Candida are able to express different gene products to adapt and grow in a variety of extreme physiological conditions, providing infections. These gene products are important for the virulence of Candida ${ }^{2,3}$.

Several virulence factors of Candida have been discovered or proposed, including adhesion, hyphal formation, phenotypic diversity and production of extracellular hydrolytic enzymes, such as phospholipases, lipases and aspartyl proteinases (Saps) ${ }^{4}$.

Once they have invaded host tissues, species of Candida have the ability to produce, in a constitutive and inducible way, hydrolytic enzymes that destroy or disorganize elements of the host cell membranes, leading to membrane dysfunction and/or physical disruption. These enzymes are proteinases, which hydrolyze peptide bonds, and phospholipases, which hydrolyze phospholipids ${ }^{5,6}$. Phospholipases act by invading and causing tissue damage in host cells, rupturing the epithelial cell membranes and allowing the ends of hyphae penetrate the cytoplasm ${ }^{5}$. Proteinase production is important for increasing the ability of certain organisms to colonize and penetrate the host tissue and deceive the host immune system, breaking a significant number of important proteins for immunity, such as immunoglobulins, complement proteins and cytokines?

Due to the increased incidence of invasive infections by Candida species ${ }^{8}$, interest in the study 
of virulence factors of these species has intensified, including the production of hydrolytic enzymes, to establish strategies for the prevention and control of candidiasis and as possible targets for the development of new therapeutic interventions'. In contrast to the species Candida albicans, only a few somewhat controversial studies exist regarding the virulence and experimental pathogenicity of other species of Candida ${ }^{10-12}$

Thus, the objective of this study was to investigate the in vitro activity of exoenzymes (phospholipases, acid proteases) in clinical isolates of four species of the genus Candida, isolated from several anatomic sites.

\section{METHODS}

\section{Strains and culture media}

The strains of Candida spp. used in this study came from cultures of hospitalized patients (both public and private hospitals in São Luís, State of Maranhão, Brazil) suspected of being infected by microorganisms. The isolates were obtained from 2007 to 2008 and belong to the collection of a private laboratory and were kindly provided for this research. The standard strain C. albicans ATCC 18804 (American Type Culture Collection, Rockville, Md) was included in the experiments. The production of aspartyl proteases and phospholipases was studied in 82 clinical isolates of $C$. albicans (47 strains), C. glabrata (10 strains), C. tropicalis (12 strains), C. parapsilosis (13 strains). The isolates were previously identified by the automated system VITEK (BioMériux, Marcy-I’Etoile, France). The yeasts were routinely grown in Sabouraud dextrose agar plates incubated at $37^{\circ} \mathrm{C}$ for $24 \mathrm{~h}$ from stock cultures in BHI-glycerol and stored at $4^{\circ} \mathrm{C}$ during the procedures.

\section{Preparation of inoculum}

The inoculum of yeast cells was made from stock cultures and incubated for 18 hours at $37^{\circ} \mathrm{C}$ in $\mathrm{BHI}$ (Brain Heart Infusion Acumedia Manufectures) or in liquid RPMI-1640 medium and standardized to approximately $10^{6} \mathrm{UFC} / \mathrm{ml}$ according to the 0.5 McFarland turbidity range (CLSI Clinical and Laboratory Standards Institute - NCCLS, 2007).

\section{Phospholipases production}

Production of phospholipases by the isolates was analyzed according the egg yolk agar plate method described by Price et $\mathrm{a}^{13}$. The test medium consisted of Sabouraud dextrose agar containing $1 \mathrm{M}$ sodium chloride, $0.005 \mathrm{M}$ calcium chloride and $2 \%$ egg yolk. Each strain was inoculated in triplicate. The Petri plates were incubated at $37^{\circ} \mathrm{C}$ and the diameters of the colonies and precipitation area plus the colony were measured 7 days postinoculation. Measurements and calculations of the phospholipase activity zone $(\mathrm{Pz})$ were made according to the method described by Price et $\mathrm{al}^{13}$. The Pz of 3 samples of each strain was measured to obtain the average $\mathrm{Pz}$. The $\mathrm{Pz}$ coefficients of the Candida strains analyzed were grouped into 4 classes: Pz between 0.9 and $1(+)$, very low Pz group; $0.89-0.80(++)$, low Pz group; $0.79-$ $0.70(+++)$ high Pz group; and $0.69(++++)$, very high Pz group.

\section{Protease production}

Determination of the protease production was performed according to Aoki et $\mathrm{al}^{14}$. The test medium consisted of plates with agar containing bovine albumin serum (BSA). Sixty milliliters of a solution containing $0.04 \mathrm{~g} \mathrm{MgSO}_{4} .7 \mathrm{H}_{2} \mathrm{O}, 0.5 \mathrm{~g} \mathrm{~K}_{2} \mathrm{HPO}_{4}, 1 \mathrm{~g} \mathrm{NaCl}$, $0.2 \mathrm{~g}$ yeast extract, $4 \mathrm{~g}$ glucose and $0.5 \mathrm{~g}$ BSA (bovine albumin serum.
Fraction V, Sigma Chem Co., St. Louis, Mo., USA) was prepared and the $\mathrm{pH}$ adjusted to 4.0 . The solution was sterilized by filtration and then mixed with $140 \mathrm{ml}$ of molten agar. Plates with this medium were incubated at $37^{\circ} \mathrm{C}$ for 7 days. Proteinase activity was measured and calculated according to the method described by Price et $\mathrm{al}^{13}$, in terms of the ratio of the colony diameter and the colony plus the inhibition zone. The study was repeated three times for each strain to calculate the average $\mathrm{Pz}$ values. The $\mathrm{Pz}$ coefficients were grouped into 4 classes as mentioned above.

\section{Statistical analysis}

Data were evaluated by the program BioEstat version 5.0. The association between positivity for hydrolytic enzyme production and Candida species and between the same positivity and the origin site was verified by the Chi square test. The Lilliefors normality test was initially performed for $\mathrm{Pz}$ numerical variables of proteinases and phospholipases. Since these variables did not show normal distribution $(p<0.05)$, they were analyzed in relation to species and anatomic sites using the Kruskal-Wallis nonparametric variance test. The significance level adopted in all tests was $5 \%$; i.e., values were considered significant when $\mathrm{p}<0.05$.

\section{RESULTS}

A total of 82 Candida species from different anatomic sites of hospitalized patients were tested for phospholipase and proteinase activities in this study. Analysis of the data obtained verified that Candida albicans was the most frequently isolated Candida spp. in different origin sites (Table 1). Phospholipase activity was detected in $56(68.3 \%)$ of the Candida isolates and proteinase activity was detected in 44 (53.6\%) of the isolates studied. Of the 47 C. albicans isolates studied, $36(76.6 \%)$ showed phospholipase activity and 23 (48.9\%) showed positivity for proteinase (Table 1).

Among the Candida species tested for phospholipase activity, C. tropicalis was the species with the highest number of positive isolates $(91.7 \%)$. C. parapsilosis was the species with the lowest number of positive isolates for enzymatic activity (15.4\%) (Table 1). Observation verified that significant differences $(\mathrm{p}<0.05)$ occurred in phospholipase production among the species analyzed.

Regarding acid proteinase production, the C. parapsilosis isolates tested showed a higher number of producers $(69.2 \%)$, followed by C. glabrata $(60 \%)$ and those exceeding the production of C. albicans, which was $48.9 \%$ (Table 1). However, among the species studied, the percentage of isolates producing proteases was not statistically different $(p>0.05)$. All the producer isolates of C. parapsilosis, except one, were from blood and catheter specimens.

The distribution of mean values of $\mathrm{Pz}$ among the 82 Candida isolates analyzed is presented in Table 2. The majority of C. albicans isolates that showed enzymatic activity $(76.6 \%)$ were considered to have very strong activity $(++++)$, both regarding phospholipase activity (69.4\%) and protease activity (64.2\%). The non-albicans species mostly showed average phospholipase activity $(++)$ and a very strong proteinase activity $(++++)$ (Table 3$)$. Statistical analysis of the phospholipase activity showed a highly significant difference between the mean $\mathrm{Pz}$ values obtained among the Candida species $(\mathrm{p}<0.0001)$ and in relation to the various anatomic sites $(\mathrm{p}=0.014)$ However, the differences between the mean $\mathrm{Pz}$ values for proteinase activity among the species $(p=0.601)$ and the anatomic sites $(\mathrm{p}=0.207)$ were not statistically significant. 
TABLE 1 - Phospholipase and acid proteinase activity of isolated Candida spp. according to the site of origin.

\begin{tabular}{|c|c|c|c|c|c|c|c|c|c|c|c|}
\hline \multirow[b]{2}{*}{ Species } & \multirow[b]{2}{*}{ Origin site } & \multicolumn{5}{|c|}{ Phospholipase } & \multicolumn{5}{|c|}{ Proteinase } \\
\hline & & positive & $\%$ & negative & $\%$ & total & positive & $\%$ & negative & $\%$ & total \\
\hline \multirow[t]{7}{*}{ Candida albicans } & urine & 17 & 73.9 & 6 & 26.1 & 23 & 7 & 30.4 & 16 & 69.6 & 23 \\
\hline & vaginal secretion & 8 & 72.7 & 3 & 27.3 & 11 & 6 & 66.7 & 3 & 33.3 & 9 \\
\hline & tracheal secretion & 7 & 87.5 & 1 & 12.5 & 8 & 6 & 75.0 & 2 & 25.0 & 8 \\
\hline & catheter & 1 & 100.0 & 0 & 0.0 & 1 & 1 & 100.0 & 0 & 0.0 & 1 \\
\hline & blood & 3 & 100.0 & 0 & 0.0 & 3 & 3 & 60.0 & 2 & 40.0 & 5 \\
\hline & peritoneal secretion & 0 & 0.0 & 1 & 100.0 & 1 & 0 & 0.0 & 1 & 100.0 & 1 \\
\hline & total & 36 & 76.6 & 11 & 23.4 & 47 & 23 & 48.9 & 24 & 51.1 & 47 \\
\hline \multirow[t]{4}{*}{ Candida parapsilosis } & urine & 2 & 66.7 & 1 & 33.3 & 3 & 1 & 33.3 & 2 & 66.7 & 3 \\
\hline & blood & 0 & 0.0 & 6 & 100.0 & 6 & 5 & 83.3 & 1 & 16.7 & 6 \\
\hline & catheter & 0 & 0.0 & 4 & 100.0 & 4 & 3 & 75.0 & 1 & 25.0 & 4 \\
\hline & total & 2 & 15.4 & 11 & 84.6 & 13 & 9 & 69.2 & 4 & 30.8 & 13 \\
\hline \multirow[t]{3}{*}{ Candida glabrata } & urine & 5 & 71.4 & 2 & 28.6 & 7 & 5 & 62.5 & 3 & 37.5 & 8 \\
\hline & tracheal secretion & 2 & 66.7 & 1 & 33.3 & 3 & 1 & 50.0 & 1 & 50.0 & 2 \\
\hline & total & 7 & 70.0 & 3 & 30.0 & 10 & 6 & 60.0 & 4 & 40.0 & 10 \\
\hline \multirow[t]{4}{*}{ Candida tropicalis } & urine & 6 & 100.0 & 0 & 0.0 & 6 & 3 & 60.0 & 2 & 40.0 & 5 \\
\hline & tracheal secretion & 4 & 100.0 & 0 & 0.0 & 4 & 2 & 40.0 & 3 & 60.0 & 5 \\
\hline & blood & 1 & 50.0 & 1 & 50.0 & 2 & 1 & 50.0 & 1 & 50.0 & 2 \\
\hline & total & 11 & 91.7 & 1 & 8.3 & 12 & 6 & 50.0 & 6 & 50.0 & 12 \\
\hline General total & & 56 & 68.3 & 26 & 31.7 & 82 & 44 & 53.7 & 38 & 46.3 & 82 \\
\hline
\end{tabular}

TABLE 2 - Mean Pz values for phospholipase and proteinase for different Candida species and sites of origin.

\begin{tabular}{|c|c|c|c|c|c|}
\hline \multirow[b]{2}{*}{ Species } & \multirow[b]{2}{*}{ Origin sites } & \multicolumn{2}{|c|}{ Phospholipase } & \multicolumn{2}{|c|}{ Proteinase } \\
\hline & & $\mathrm{n}$ & $\bar{x} \pm \mathrm{s}$ & $\mathrm{n}$ & $\bar{x} \pm \mathrm{s}$ \\
\hline \multirow[t]{5}{*}{ Candida albicans } & urine & 17 & $0.62 \pm 0.13$ & 7 & $0.67 \pm 0.10$ \\
\hline & vaginal secretion & 8 & $0.69 \pm 0.10$ & 6 & $0.67 \pm 0.14$ \\
\hline & tracheal secretion & 7 & $0.69 \pm 0.13$ & 6 & $0.67 \pm 0.16$ \\
\hline & catheter & 1 & $0.61 \pm 0.00$ & 1 & $0.52 \pm 0.00$ \\
\hline & blood & 3 & $0.86 \pm 0.15$ & 3 & $0.71 \pm 0.07$ \\
\hline \multirow[t]{3}{*}{ Candida parapsilosis } & urine & 2 & $0.87 \pm 0.02$ & 1 & $0.73 \pm 0.00$ \\
\hline & blood & & & 5 & $0.64 \pm 0.05$ \\
\hline & catheter & & & 3 & $0.61 \pm 0.07$ \\
\hline \multirow[t]{2}{*}{ Candida glabrata } & urine & 5 & $0.77 \pm 0.11$ & 5 & $0.62 \pm 0.15$ \\
\hline & tracheal secretion & 2 & $0.81 \pm 0.08$ & 1 & $0.73 \pm 0.00$ \\
\hline \multirow[t]{3}{*}{ Candida tropicalis } & urine & 6 & $0.8 \pm 0.16$ & 3 & $0.64 \pm 0.08$ \\
\hline & tracheal secretion & 4 & $0.83 \pm 0.04$ & 2 & $0.65 \pm 0.06$ \\
\hline & blood & 1 & $0.85 \pm 0.00$ & 1 & $0.86 \pm 0.00$ \\
\hline
\end{tabular}

TABLE 3 - Distribution of the $\mathrm{Pz}^{*}$ value among the isolates of different Candida species.

\begin{tabular}{|c|c|c|c|c|}
\hline \multirow[b]{2}{*}{ Pz Values } & \multicolumn{2}{|c|}{ Candida albicans } & \multicolumn{2}{|c|}{ Candida non-albicans } \\
\hline & phospholipase & proteinase & phospholipase & proteinase \\
\hline$\leq 0.69++++$ & 24 & 13 & 2 & 16 \\
\hline $0.70-0.79+++$ & 3 & 8 & 1 & 3 \\
\hline $0.80-0.89++$ & 7 & 2 & 15 & 2 \\
\hline $0.90-0.99+$ & 2 & 0 & 2 & 0 \\
\hline Total (\%) & $36(76.6 \%)$ & $23(48.9 \%)$ & $20(57.1 \%)$ & $21(60.0 \%)$ \\
\hline
\end{tabular}

*Pz: activity zone for phospholipase and proteinase, ++++ : very strong, +++ : strong, ++: average, +: weak/poor.
The majority of isolates positive for phospholipases were from tracheal secretion $(86.7 \%)$ and urine samples (76.9\%) (Table 1). This difference was statistically significant, with $\chi^{2}=12.6$ and $\mathrm{p}=0.0277$. For proteinase activity, analysis of the isolates revealed no significant differences in enzymatic production between the different anatomic sites $\left(\chi^{2}=7.2\right.$ and $\mathrm{p}=0.2077$; Table 1$)$.

In the present study, $29.3 \%$ of the isolates produced both phospholipase and proteinase, including 16 of the 27 strains of C. albicans, 5 of the 12 C. tropicalis, 1 of the 13 C. parapsilosis and 2 of the 10 strains of C. glabrata.

\section{DISCUSSION}

Phospholipase and proteinase activities are considered to play important roles in the pathogenesis of opportunistic fungi. The roles of these two hydrolytic enzymes in C. albicans and other yeast species seem to be related to species virulence ${ }^{15,16}$. The present study aimed to determine in vitro phospholipase and proteinase activities in 82 Candida isolates, which were collected from several anatomically distinct sites of hospitalized patients. In this work, phospholipase and proteinase activities were observed in both the C. albicans and C. non-albicans isolates studied.

C. tropicalis proved to be the species with the highest number of positive isolates and C. parapsilosis was the species with the lowest number of positive isolates for phospholipase activity, a difference that was statistically significant. These observations are in disagreement with the results obtained by Rorig et $\mathrm{a}^{17}$, who determined C. albicans as the largest enzymatic producer, with neither of the species C. glabrata and C. parapsilosis revealing phospholipase and proteinase activities. Similarly, a study by Negri et $\mathrm{a}^{18}$ observed that only one $C$. tropicalis isolate out of seven obtained from a central venous catheter was positive for phospholipases. 
Regarding acid proteinase production, the $C$. parapsilosis isolates tested showed a higher number of producers ( 9 out of 13 strains), followed by C. glabrata and those exceeding the production of C. albicans; however, this difference was not statistically significant.

De Bernardis et $\mathrm{al}^{10}$ reported high acid proteinase activity in vitro in all C. parapsilosis strain isolates from outpatients, regardless of whether they presented candidemia or not or whether they were HIV+ or HIV-. While investigating the presence of virulence factors in 33 C. parapsilosis strains, 19 of which were isolated from blood cultures of hospitalized fungemia patients, Dagdeviren et a ${ }^{19}$ observed that $42.42 \%$ of these strains were acid proteinase producers and $79 \%$ showed high activity. Their results are in agreement with the current findings, in which $69.2 \%$ of $C$. parapsilosis isolates were acid proteinase producers with high $\mathrm{Pz}$ (average $\mathrm{Pz}=0.64$ ). However, Kantarcioglu \& Yucel ${ }^{15}$ showed that the highest producer species of phospholipases was C. albicans (93.3\%) and only a few strains of C. kefyr and C. glabrata behaved similarly. In the same study, the authors observed proteinase activity in isolates of C. albicans and in a few isolates of C. kefyr, C. lipolytica, C. parapsilosis and C. tropicalis, and again C. albicans was the largest producer (95\%). Both these results differ from those reported here.

In this work, the majority of the C. albicans enzyme producers were considered to have very strong activity, both for phospholipase activity and proteinase activity. The non-albicans species showed mostly average phospholipase activity and very strong proteinase activity. In contrast to these results, while studying Candida samples from healthy people, Oksuz et $\mathrm{al}^{20}$ verified that the majority of the C. albicans isolates showing enzyme activity were ranked as strong. In the same study, most of the Candida non-albicans isolates that showed phospholipase and proteinase activity were classified as very strong activity for phospholipase and low for proteinase. In this study, the frequencies of phospholipase and proteinase activity in C. albicans were 53 and $56.7 \%$, respectively, while for $C$. non-albicans isolates, the values obtained were 17 and $43.9 \%$, showing that these frequencies were lower than those obtained in the present study and those reported in other studies.

Different frequencies of enzymatic activity have been reported in Candida spp., isolated from different anatomic sites ${ }^{15,20,21}$. The isolates analyzed in this work produced phospholipases independent of the species and this production also varied according to the anatomic site. The majority of the isolates positive for phospholipases were from urine and tracheal secretion samples, although proportionality in the distribution of Candida species among the clinical materials is not observed, since higher prevalence of these strains was determined in such sites. Kantarcioglu \& Yucel verified that the highest phospholipase activity was determined in respiratory tract isolates ${ }^{15}$. In contrast, Oksuz et $\mathrm{a}^{20}$ obtained higher extracellular phospholipase activity in isolates from oral (59\%) and fecal samples (42.8\%), respectively. Regarding proteinase activity among the isolates analyzed, no difference in enzymatic production was observed between the different origin sites, in disagreement with the findings of Kantarcioglu \& Yucel regarding proteinase activity, which was higher in isolates from the respiratory tract and urogenital system ${ }^{15}$.

Few studies have investigated phospholipase and proteinase production together in the same strains. In this study, $29.3 \%$ of the isolates produced both phospholipases and proteinases. Kantarcioglu \& Yucel ${ }^{15}$ observed that 56 out of 60 strains of C. albicans and 2 out of 4 strains of $C$. kefyr tested produced both enzymes, while the other strains studied showed no capacity for producing one of the enzymes analyzed. A study conducted by Shimizu et al ${ }^{22}$ investigated the ability of different Candida species to simultaneously produce hyaluronidase, chondroitin sulfatase, protease and phospholipase, in order to evaluate whether they were related to Candida pathogenicity. They determined that with the exception of the C. albicans strains, none of the strains produced all four enzymes simultaneously, in contrast to the results obtained in this study.

Candida tropicalis is a pathogen known to be important in nosocomial infections ${ }^{12,18}$. The majority of the $C$. tropicalis isolates (11 of 12 isolates analyzed) showed phospholipase activity, an enzyme considered to be an important virulence factor and that is probably involved in the pathogenesis of C. albicans species ${ }^{23-25}$. However, in the present results, phospholipase production by $C$. tropicalis isolates was considered weak or average (average $\mathrm{Pz}=0.83$ ). C. parapsilosis has also been indicated as a species capable of causing infection. More than $30 \%$ of the notified fungemias during this decade have been associated with C. parapsilosis. The rise in fungemia caused by this species is explained by the high capacity of the species to adhere to plastic surfaces, such as catheters, and probably due to the extracellular hydrolytic enzymes they can produce ${ }^{19}$. The C. parapsilosis isolates analyzed in this research were large acid protease producers, as were those of C. tropicalis and C. glabrata.

The results for C. glabrata are also important and show that this species can produce acid proteinase in vitro, which could be related to species virulence. These data are different from most of those published in the literature, which affirm that secreted proteinase activity has no function in relation to C. glabrata virulence ${ }^{11}$ and that C. glabrata does not seem to produce significant levels of extracellular proteinase activity, at least in vitro ${ }^{15}$.

In general, the present results showed that $C$. non-albicans isolates and those of $C$. albicans, are large producers of hydrolytic enzymes and, consequently, they might be capable of causing infection under favorable conditions. The production levels determined were higher than those reported for Candida isolates from healthy individuals. According to these results, proteinase and phospholipase expression can vary according to Candida species and strain. Analysis of the results also showed that some species, such as C. parapisilosis, which were previously considered SAP-negative, and C.glabrata, considered to be a low producer of protease activity, were, in fact, proteolytic.

Analysis of the results obtained indicates differences in phospholipase and acid proteinase production between Candida spp. isolates from different sources. This study suggests that the pathogenicity of Candida might be related to the site of infection.

\section{CONFLICT OF INTEREST}

The authors declare that there is no conflict of interest.

\section{REFERENCES}

1. Landstrom T, Sobel J. Nosocomial candiduria: a review. Clin Infect Dis 2001; 32:1602-1607.

2. Cheng MF, Yang YL, Yao TJ, Lin CY, Liu JS, Tang RB, et al. Risk factors for fatal candidemia caused by Candida albicans and non-albicans Candida species. BMC Infect Dis 2005; 5:1-5.

3. Colombo AL, Nakagawa Z, Valdetaro F, Branchini MLM, Kussano EJU, Nucci M. Susceptibility profile of 200 bloodstream isolates of Candida spp collected from Brazilian tertiary care hospitals. Med Mycol 2003; 41:235-239. 
4. Naglik JR, Rodgers CA, Shirlaw PJ, Dobbie JL, Fernandes-Naglik LL, Greenspan D. Differential expression of Candida albicans secreted aspartyl protease and phospholipase B genes in humans correlates with oral and vaginal infections. J Infect Dis 2003; 188:465-475.

5. Ghannoum MA. Potential role of phospholipases in virulence and fungal pathogenesis. Clin Microbiol Rev 2000; 13:122-143.

6. Julian R, NaglikJR, Challacombe SJ. Candida albicans secreted aspartyl proteinase in virulence and pathogenesis. Microbiol. Mol Biol Rev 2003; 67:400-428.

7. Hube B. Candida albicans secreted aspartyl- proteinases. Curr Top Med Mycol 1996; 1:55-69.

8. Asmundsdottir LR, Erlendsdottir H, Haraldsson G, Guo H, Xu J, Gottfredsson M. Molecular epidemiology of candidemia: evidence of clusters of smoldering nosocomial infections. Clin Infect Dis 2008; 47:17-24.

9. Perfect JR. Fungal virulence genes as targets for antifungal chemoterapy. Antimicrob. Agents Chemoter 1996; 40:1577-1583.

10. De Bernardis FF, Mondello R, San Millan J, Cassone A. Biotyping and virulence properties of skin isolates of Candida parapsilosis. J Clin Microbiol 1999; 37:3481-3486.

11. Kaur R, Domergue R, Zupancic ML, Cormack MB. Curr Opin Microbiol 2005 ; 8:378-384

12. Kothavade R, Kura MM, Valand AG, Panthaki MH. Candida tropicalis: its prevalence, pathogenicity and increasing resistance to fluconazole. J Med Microbiol 2010; 59:873-880.

13. Price MF, Wilkinson ID, Gentry LO. Plate methods for detection of phospholipase activity in Candida albicans. Saboraudia 1982; 20:7-14.

14. Aoki S, Ito Kuwa S, Nakamura Y, Masuhara T. Comparative pathogenicity of wild- type strains and respiratory mutants of Candida albicans in mice. Zol Bakt 1990; 273:332-343.

15. Kantarcioglu AS, Yucel A. Phospholipase and protease activities in clinical Candida isolates with reference to the sources of strains. Mycoses 2002; 45:160-165.

16. Xu J, Mitchell TG. Geographical differences in human oral yeast flora. Clin Infect Dis 2003; 36:221-222.

17. Rorig KCO, Colacite J, Abegg MA. Production of virulence factors in vitro by pathogenic species of the genus Candida. Rev Soc Bras Med Trop 2009; 42:225-227.

18. Negri M, Martins M, Henriques M, Svidzinski TIE, Azevedo J, Oliveira R. Examination of potential virulence factors of Candida tropicalis clinical isolates from hospitalized patients. Mycopathologia 2010; 169:175-182.

19. Dagdeviren M, Cerikcioglu N, Karavus M. Acid proteinase, phospholipase and adherence properties of Candida parapsilosis strains isolated from clinical specimens of hospitalized patients. Mycoses 2005; 48:321-326.

20. Oksuz S, Sahin I, Yildirim M, Gulcan A, Yavuz T, Kaya D, et al. Phospholipase and proteinase activities in different Candida species isolated from anatomically distinct sites of healthy adults. Jpn. J Infect Dis 2007; 60:280-283.

21. Vidotto V, Kogo- Ítalo CY, Milano R. Correlation between germ tube production, phospholipase activity and distribution and serotype in Candida albicans. Rev Iberoam Micol 1999; 6:208-210.

22. Shimizu MT, Almeida NQ FantinatoV, Unterkircher CS. Studies on hyaluronidase, chondroitin sulphatase, proteinase and phospholipase secreted by Candida species. Mycoses 1996; 39:161-167.

23. Cole GT, Lynn KT, Seshan KR. An animal model for oropharyngeal, esophageal and gastric candidosis. Mycoses 1990; 33:7-19.

24. Ibrahim AS, Mirbod F, Filler SG, Banno Y, Cole GT, Kitajima Y, et al. Evidence implicating phospholipase as a virulence factor of Candida albicans. Infect Immun 1995; 63:1993-1998.

25. Yamamoto T, Nohara K, Uchida K, Yamaguchi H. Purification and characterization of secretory proteinase of Candida albicans. Microbiol Immunol 1992; 36:637-641. 